
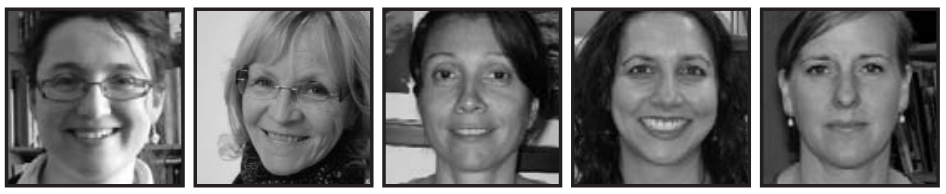

\title{
Teacher Inquiry for Educational Change
}

Danielle Couture, Judith McBride, Sujata Saha, Denise Schellhase \& Kelly Von Eschen, Heritage Regional High School

\section{ABSTRACT}

The inquiries of professionals involved in the development of a centre for inquiry into educational practice in a secondary school are fostered through professional conversation among teachers, support and professional staff undertaking research on practice. A framework for the development of the work done in the centre is briefly reviewed. Snapshots of various experiences and products illustrate evolving understandings of inquiry and evidence of ways in which it supports student learning and developing teaching practices in light of local curricular reforms. ${ }^{1}$

\section{Teacher Inquiry for Educational Change}

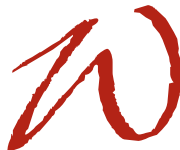

ithin the context of curricular reforms (QEP, 2004), education in Quebec has been reconceptualized to reflect societal demands for a support system for teachers and learners with a focus on success for all students achieved through cooperation, problem solving and partnership (Smith, Foster, \& Donahue, 1999). However, systemic transformation is rarely without confusion or conflict, and one means to approach such change is to anticipate, confront, and problematize it, using systematic processes such as those of the practitioner researcher. The purpose of this paper is to present a local illustration of the context and application of the inquiry process. Snapshots of various inquiries highlighting problems and progress follow brief summaries of theories framing the work. Finally, a possible next step is put forward. 


\section{The Inquiry Context}

Heritage Regional High School (HRHS) is a suburban secondary school located outside of Montreal, Quebec, serving the needs of 1800 mixed-ability and culturally diverse students in an array of programs. These include the prescribed provincial curriculum; enriched English, French and Mathematics courses; extended Secondary I, and work-oriented pathways; Fine Arts Focus, International Baccalaureate, and Sports Excellence options. A team of six administrators, 105 teachers, 28 support and professional staff deliver programs. Ours is a large, busy, and extremely complex community, with a mission to provide a "warm and caring environment, which...encourages excellence and celebrates, with pride, the efforts of those who teach and learn" (HRHS, 2009). However, like any school, HRHS is not without its problems.

The HRHS Centre for Inquiry Into Professional Practice (CIPP) grew from weekly meetings begun in 2008. The purpose is to support the endeavors of staff conducting research on practice. Participants have included administrators, teachers, professional, support and secretarial staff. Our professional conversations focus on various problems, possible solutions, as well as a variety of inquiry processes.

A framework for building the CIPP. Various theoretical perspectives frame the CIPP project. Professional conversation supports our developing inquiry community, and provides a context for critical discussion of the school's academic and social issues, research methods, and progress of individual inquiries. Guidelines for various projects are found in the narrative inquiry, self-study, and action research traditions. This paper will focus on the latter.

Conversation as a medium for reflection and change. As a generic term, conversation may be applied to varying language activities in which one's experience is recounted to an other. In a research context, conversation has been used as an alternative or complement to the interview tradition, allowing equal participation in the consideration of assumptions, questions, and ideas. Van Manen (1992) understands conversation as a relational triad. One speaker engages with another, and together they engage with an object, idea, experience, or topic, through question and answer, expression and interpretation of commentary. Thus, conversation may be understood as a collaborative and collective endeavor, fostering reflection and providing an opportunity for shared understanding of experiences, ideas, or phenomena.

Professional conversation fosters the establishment of a discourse community (Rath, 2002), characterized by flexible relationships, and an atmosphere of mutual 
respect and trust, each member contributing to the form and topic of the conversation (Clandinin \& Connelly, 1998; Rust, 2002). In the case of the CIPP, professionals on equal footing explore and reflect upon the fundamentals of their work as educators and researchers, leading through action to the construction of theoretical and practical knowledge (Connelly \& Clandinin, 1999; Rath, 2002; Rust, 2002; Whitehead \& McNiff, 2006).

Action research. Action research is generally conceived of as a systematic, cyclical process of reflection on, and change to, professional practice (Arhar, Holly, \& Kasten, 2001; Drummond \& Themessl-Huber, 2007; Heydenrych, 2001; Mills, 2003; Stringer, Christensen, \& Baldwin, 2010; Whitehead \& McNiff, 2006). With experience, the inquiry process becomes embedded in the professional's repertoire (Clarke \& Erickson, 2003). Outcomes include not simply isolated improvements to teaching and learning. As inquirers construct practical and theoretical professional knowledge, they move to a position where they may make a contribution beyond the local to the broader educational research context.

For our purpose in the CIPP, action research is defined as systematic investigation involving reflection and the gathering of information on teaching and learning in academic and social contexts. The goal is to identify and solve problems, initiate positive change in specific practices and the school environment in general, and to publicly validate findings. Whitehead and McNiff (2006) suggest a series of questions to guide the inquiry process.

- What is my concern?

- Why am I concerned?

- What experiences can I describe to show why I am concerned?

- What can I do about my concern?

- What kind of data will I gather to show the situation as it unfolds?

- How will I explain my educational influences in learning? (p. 89)

These have loosely guided our various inquiries.

\section{Snapshots of Inquiry on Practice}

Professional conversation supports our developing inquiry community, and provides a context for critical discussion of demands made by recent curricular initiatives, the school's academic and social challenges, methods supporting inquiry into problems of practice, and progress of individual inquiries. The following snapshots 
serve to illustrate a sampling of CIPP action research projects. The first is of Danielle, an early career science teacher exploring inquiry-based learning. Denise, investigating classroom discourse, teaches history. Kelly and Sujata are math teachers developing an inquiry framework to support curricular demands of the reform.

Danielle Couture on inquiry in the Science class. For the last four years I had the opportunity to teach the same students from grade 7 to 10 . My teaching style matured as the students had, yet I constantly feared that the mistakes from my rookie year would return to haunt me. This year would be different. It is my fifth year teaching, and the first time I received an entirely new batch of students. Needless to say I was nervous. Nervousness and fear have always compelled me to modify and better my practice. It seemed like a test. Would I be able to adapt to these new students? Would I be able to approach Science in the same manner I had in previous years?

The ominous bell marking the beginning of the school year rang and I stood by the door anticipating new faces. They filed into class slowly, eyeing me suspiciously with a pre-glazed expression of students expecting a bombardment of facts, one question imprinted on the back of their minds, "But why are we learning this? We will never use it again." Through my readings on gender differences, multiple intelligences and learning styles, along with experience, I have developed a student-centered approach to learning. This "but why" attitude was not new to me, and I believed that there was only one person who could answer that question-the student.

The following is an account of different activities, and methods that I am using with my students to foster inner motivation and responsibility, and to answer the elusive "but why" question that often stifles curiosity, through inquiry-based learning. Looking back now, I have to admit that it was difficult at times, but I would not change a thing. The lessons learned for my students and myself were astonishing.

Problematic and selection of the question. Whether or not it was due to familiarity with my teaching style or to the expectation of fact-driven science instruction, I found my students lacking inner motivation, independence, and responsibility for their learning. They could not remember dates of quizzes or exams. They forgot to bring materials for projects and class, and they seemed unable to organize their time. The lack of these essentials seemed problematic. I am teaching grade 9 and 10, my students are quickly approaching final graduation requirements, and the less structured learning environment of CEGEP. I feared that if they were unable to develop their time management skills and responsibility for learning, they would very shortly encounter an incredible wall. 


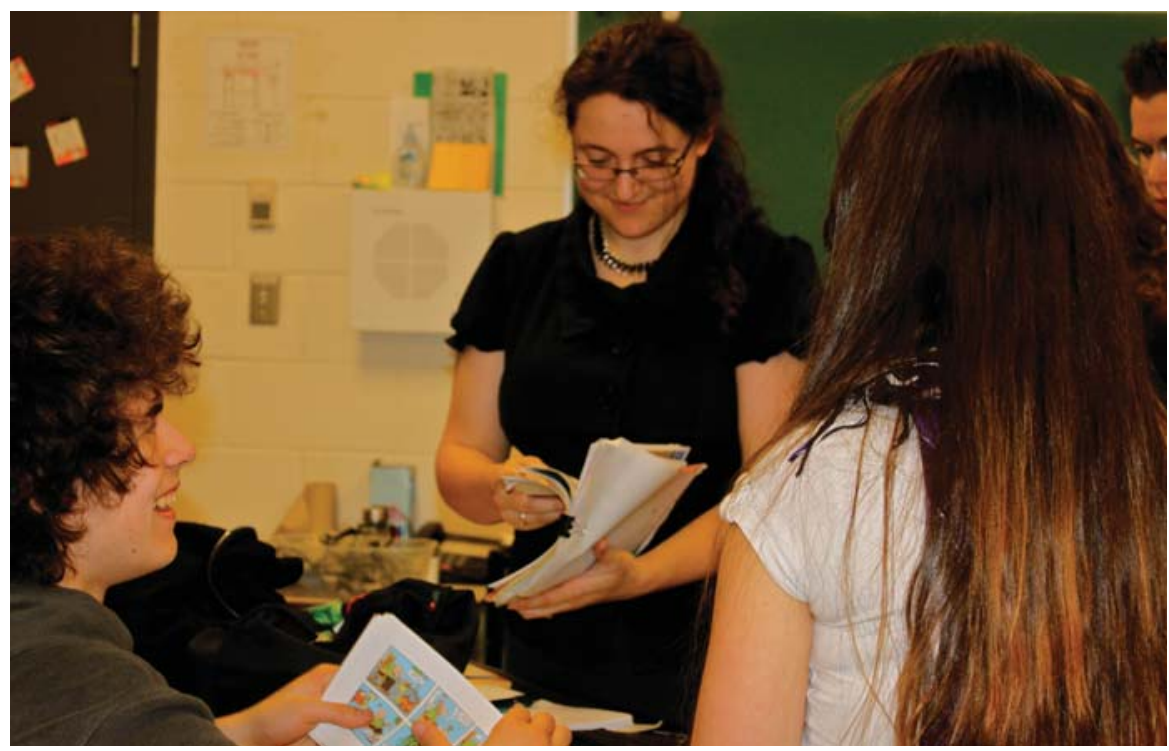

Fig. 1: Danielle engages with students in her student-centered inquiry Science class

Was the lack of responsibility for learning due to disinterest in the course, or maybe a dissonance between my teaching and their learning styles? These questions led me to join the Action Research Group, people with whom I can talk, and refer to, who are also seeking to better their teaching. After trying to pinpoint exactly what my intent in action research was, I came up with my question: "How can we create an environment in which students will develop their independence for learning through inner motivation?"The question, like my teaching, is forever in a tumultuous dance. It changes with new situations. It is molded by individuals I encounter, leaving an impression as they pass. The only thing that I know for sure is that it definitely should be "How can we create?" instead of "How can I create?" The choice of pronoun is essential, for the "we" refers to my students and me. I can question my practices as much as I like, change minor things, for example, give them schedules or build websites-both of which were tried with little success. If the students will not use the tools how can they be effective? I realized that the students must come up with the tools, must find the everyday relevance of science. I must provide them with the platform and guidance when needed.

Solution adopted and information gathering. Seeing as I hoped to help develop fully functional, independent citizens and individuals, I decided to put learning into their hands for certain inquiry-based projects in an attempt to foster responsibility for learning. I found it easier to interest the students in this type of project by 
discussing major events covered extensively by the media, such as the toy recall in 2009-2010 and the British Petroleum (BP) oil spill.

Obviously, independence, motivation and responsibility for learning are not elements that can be easily quantified. Students do not have small meters showing their development. In order to verify the level of responsibility being developed, I observed their organizational skills, their use of resources, and innovations. I noted when materials were brought in. I considered the amount of idle time spent during periods assigned to projects.

Project 1: The Safe Toy Company 2009-2010. The first project was done in the context of an entrepreneurship contest run by the Quebec government. The students had recently heard about various toy recalls that plagued 2008-2009. This concern inspired a discussion on toy safety and those made of natural materials, such as wood. The class came up with an idea. Each group would become a toy company and would design a wooden toy, giving its specifications and detailed instructions for its construction.

Chessboards and tic-tac-toe games were created, but to my surprise, many students went above and beyond my expectations, designing and creating pinball machines, marble labyrinths and foosball tables. Students were highly interested in the creation and fabrication of their games, not to mention that they also wanted to play with them. They were intrigued by the lengthy process of toy manufacturing, and enjoyed working with wood. Through the Safe Toy Company, the students took the first steps to become responsible for their learning. They chose the toy, came up with specifications, and built products within a limited time frame. They organized their time, materials and roles within groups. I began to note that tardiness had declined, students brought materials, and they were ready to work.

Project 2: Re-creating BP. It was very difficult not to talk about the BP oil spill in the first few days of class. Everyone had heard about it, every student had an opinion, yet no one really knew the extent of the damage or about the clean-up trials taking place. This seemed like an opportunity to re-create a miniature oil spill in the class -in this case vegetable oil.

Students were asked to bring in materials that they believed would help contain and clean up the watery mess. What surprised me was the independent research the students performed. They wanted to select the best possible materialshairbrushes, sponges, cotton balls and other sanitary products. It was amazing to see 
how the different materials reacted with the oil, and to see the difficulty in containing it. What was particularly interesting was that many of the materials worked, yet the students still remarked that there was an oily gleam covering the surface of the aquarium. Through the clean-up efforts, the students understood issues surrounding the spill, and aspects of the scientific method as well.

Project 3: Full-fledged inquiry - end-of-year project. The preliminary results of the Safe Toy Company and the BP Oil Spill encouraged me to take a further step, relinquishing more of my job as teacher, and adopting the role of facilitator. In full-fledged inquiry, students were allowed to select their topic and the type of project, whether it was research-based, experimental, or involving technical design. Within the six classes that were blocked off for the project, students were encouraged to establish their own time lines and take on the responsibility for making arrangements with the lab technicians or librarians as needed.

Students brought in a vast array of poster presentations, experiments, and a Rube Goldberg Machine that could only enter the school through the merchandise delivery door. Students became researchers, scientists, builders and even psychologists using the class as their test subjects. One of the more memorable groups was the Hockey Stick Boys. No matter what I asked to support them in their development as inquirers-What is the purpose of the project? What are you trying to accomplish? What is your question?--They stated, matter of factly, "Hockey sticks." Yet even this group understood, toward the end, the complexity of the research required to reproduce the manufacturing process of hockey sticks. The group actually required additional time to complete the project, and carefully scheduled moments with the technician, while balancing the demands of the science class. Responsibility, motivation, and organization were instilled in the group. At the end of the year, they presented their research, experiment, or construction to their peers, administrators and other teachers involved in action research. For the first time, I had no problem finding volunteers. They all wanted to present first, to show their handiwork, their research, and their results.

Final results and outcomes. Inquiry-based learning was beyond anything that I could have imagined. Not only did the students take up the challenge that I placed before them, but also they had a greater gift at the end-pride. I had never seen students so anxious and proud of their accomplishments. They were hoping that the vice-principals would visit the class, a rare wish for grade 9 students! They created wonderful projects, every one finished, and reflecting students' inner sense of responsibility. 
I realized that I could, from time to time, give up my position as the textbook teacher, and the students would still learn, and the lessons learned might be, at times, more beneficial and definitely more memorable to my students and myself. In an attempt to extend my experiment, I debated how to introduce full-fledged inquiry as a permanent element in my classroom. I worried too much. Within the first few weeks of this school year, one of my grade ten students, a friend of a former student asked, "Miss, can I do my inquiry project on go-karts?" The idea spread by itself through the class. I was speechless. Not only were students looking forward to tackling the project with zeal, but the word had also spread to new students who had not experienced my inquiry classroom. Since then, they have all come to my class with ideas, expectations and motivation.

\section{Denise Schellhase on classroom discourse in the History and Citizenship} class. I am originally from British Columbia where I earned my Bachelor's degree in History and Anthropology, and a teaching certificate at Simon Fraser University. I am in my 12th year of teaching, and teach Canadian history to grade nine and ten students. At present, I am working on a Master's Degree in Education at McGill University. Year one. One area of my teaching practice I have always found problematic is my use of class discussion. Often, when there was a topic to be discussed at length in class, I asked a general question to the whole class and let various students share their opinions. Other students would respond to these opinions (and so would I), but I frequently found that students' opinions tended to be unfounded. Certain students monopolized our discussions, there was a general lack of respect or reflection on ideas that were "different." In the end, discussions often turned into debates, where students were constantly trying to "one up" each other. In short, there wasn't a whole lot of learning taking place.

When I joined the Action Research Group, therefore, I chose to focus my research on class discussions and how I could implement a more meaningful, discussion-based curriculum in my classroom. I researched various strategies on how to teach discussion techniques and how to structure discussions so that they could be opportunities for students to encounter, engage with, and build new knowledge.

First steps. I started my inquiry by placing all the chairs in a circle and facilitating a discussion with my students on a topic which I figured they would have some opinions about already - at the time, it was the 2008, United States presidential election. I videotaped this discussion. I had no real plan in mind. I simply wanted to observe how we were discussing ideas as a class, and I wanted to see whether changing the physical space of the classroom would have an effect upon the way we 


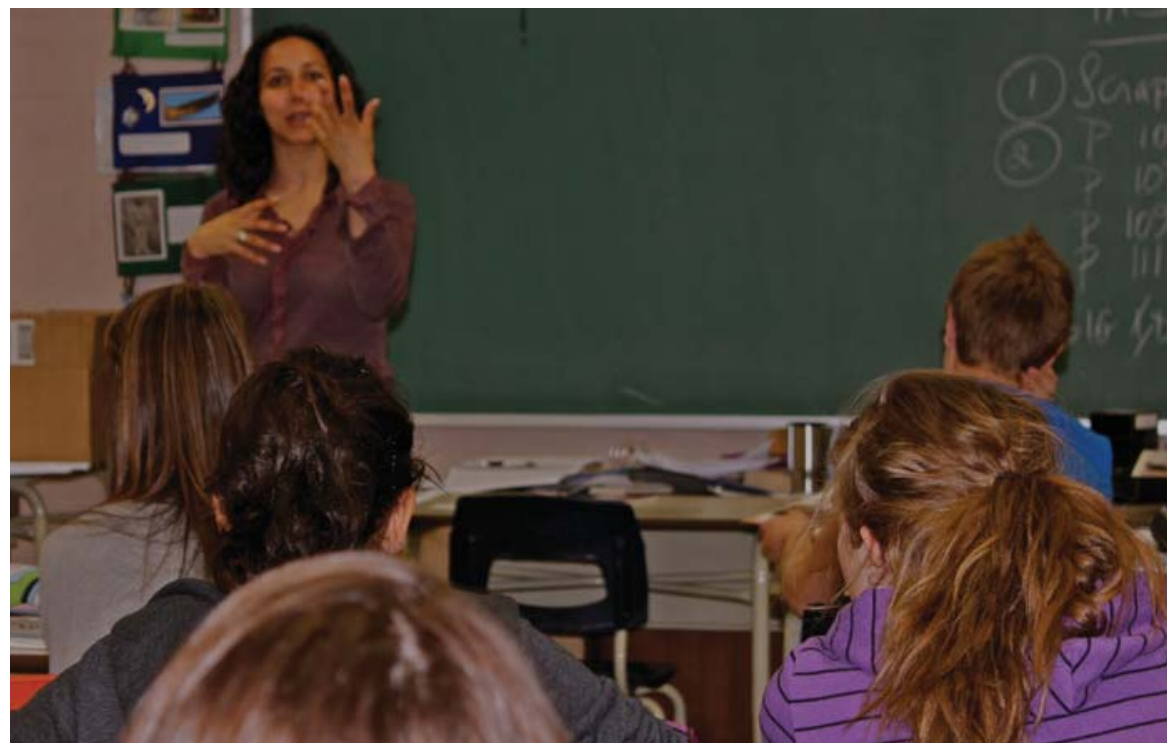

Fig. 2: Denise leads her students in discussion in History and Citizenship class

discussed.Videotaping the discussion definitely changed the nature of the discussion in that students were, overall, more respectful and self-conscious. More importantly, I showed the videotape to the action research group for feedback, and for the students to get their feedback and observations. During our action research group analysis, I asked my colleagues to write what they saw in the video. While my students were watching the video, however, I asked them to track who spoke, the order in which they spoke, and whether their comments were related to what another student had said. The comments I received were very interesting. The teachers noticed details which had eluded me, such as students' body language, while the students were very critical of how they presented themselves publicly and how little some students in the class spoke or responded to what others had said.

In order to see what was transpiring during our class discussions, I invited a colleague's leadership class to observe my students during a discussion. My hope was that his students could offer critical feedback to my students on how best to interact during a discussion. I also wanted them to tell us what they saw going on. Once again, the activity proved to be extraordinarily fruitful. My colleague's class made an outside ring around my discussion group, and in this fishbowl configuration my students discussed the topic of democracy and whether Canadian society was truly democratic. The feedback we received was extremely useful. Though some of the comments made by the leadership students seemed a little harsh at the time, they were honest, 
and I felt that my students appreciated getting critical feedback from older peers instead of from me. I also felt that the critiques encouraged them to reflect on their interactions during discussions and to consider how they might modify or change their way of responding to others or sharing their opinions.

Using the data I collected from the videotapes, my journaling after discussions, and the feedback from the leadership class, my students and I sat down together to draw up a list of criteria with which I would evaluate them. In the QEP one of the competencies which I am expected to assess is Citizenship, and I had been struggling both to define what this meant, and to come up with meaningful activities which gave students the opportunity to practice it. Discussions, I concluded, could be a perfect vehicle for putting citizenship education into action. If I define citizenship according to the parameters set by Crick and Joldersma (2007), then the practice of citizenship must be embedded within social interaction.

Once I had my list of criteria from the students, I came up with descriptors and placed them on a grid (see Figure 3 below).

\begin{tabular}{|c|c|c|c|c|c|}
\hline CRITERIA & 1 & 2 & 3 & 4 & 5 \\
\hline $\begin{array}{l}\text { Quality of } \\
\text { Comments } \\
\text { (c1) }\end{array}$ & $\begin{array}{l}\text { Student does not } \\
\text { contribute to the } \\
\text { discussion. }\end{array}$ & $\begin{array}{l}\text { Student's discus- } \\
\text { sion points simply } \\
\text { echo what has } \\
\text { already been said. } \\
\text { Little understand- } \\
\text { ing of the topic is } \\
\text { demonstrated. }\end{array}$ & $\begin{array}{l}\text { Student shares } \\
\text { good thoughts } \\
\text { and ideas with the } \\
\text { group which help } \\
\text { to keep the dis- } \\
\text { cussion flowing. } \\
\text { His/her comments } \\
\text { prompt others to } \\
\text { clarify their posi- } \\
\text { tions/points. }\end{array}$ & $\begin{array}{l}\text { Student's com- } \\
\text { ments are } \\
\text { thoughtful and } \\
\text { provocative. They } \\
\text { demonstrate a } \\
\text { sound knowledge } \\
\text { of the topic. } \\
\text { Student chal- } \\
\text { lenges the } \\
\text { thoughts of those } \\
\text { who have spoken } \\
\text { previously. }\end{array}$ & $\begin{array}{l}\text { Student's com- } \\
\text { ments show } \\
\text { depth of thought } \\
\text { and understand- } \\
\text { ing of the topic. } \\
\text { He/she has added } \\
\text { new and con- } \\
\text { structive points to } \\
\text { the discussion. } \\
\text { Student probes } \\
\text { others' positions } \\
\text { through thought- } \\
\text { ful questioning. }\end{array}$ \\
\hline $\begin{array}{l}\text { Listening } \\
\text { Skills } \\
\text { (c3) }\end{array}$ & $\begin{array}{l}\text { Student's body } \\
\text { language does } \\
\text { not demonstrate } \\
\text { an interest in the } \\
\text { discussion. }\end{array}$ & $\begin{array}{l}\text { Student's body } \\
\text { language sug- } \\
\text { gests that student } \\
\text { is not actively fol- } \\
\text { lowing the con- } \\
\text { versation at all } \\
\text { times. }\end{array}$ & $\begin{array}{l}\text { Student's body } \\
\text { language demon- } \\
\text { strates active lis- } \\
\text { tening skills. }\end{array}$ & $\begin{array}{l}\text { Student's body } \\
\text { language demon- } \\
\text { strates active lis- } \\
\text { tening skills. } \\
\text { His/her comments } \\
\text { reflect considera- } \\
\text { tion of other } \\
\text { points of view. }\end{array}$ & $\begin{array}{l}\text { Student's body } \\
\text { language demon- } \\
\text { strates active lis- } \\
\text { tening skills. } \\
\text { Through his/her } \\
\text { comments, it is } \\
\text { evident that } \\
\text { he/she has been } \\
\text { following the con- } \\
\text { versation very } \\
\text { closely as com- } \\
\text { ments build upon } \\
\text { what others have } \\
\text { said. }\end{array}$ \\
\hline
\end{tabular}




\begin{tabular}{|c|c|c|c|c|c|}
\hline CRITERIA & 1 & 2 & 3 & 4 & 5 \\
\hline $\begin{array}{l}\text { Respect } \\
\text { (c3) }\end{array}$ & $\begin{array}{l}\text { Student often } \\
\text { interrupts others } \\
\text { while they are } \\
\text { speaking. }\end{array}$ & $\begin{array}{l}\text { Student does not } \\
\text { always wait } \\
\text { his/her turn } \\
\text { before speaking. }\end{array}$ & $\begin{array}{l}\text { Student always } \\
\text { waits his/her turn } \\
\text { before speaking } \\
\text { and never inter- } \\
\text { rupts others by } \\
\text { adding unneces- } \\
\text { sary comments. }\end{array}$ & $\begin{array}{l}\text { Student waits } \\
\text { his/her turn } \\
\text { before speaking. } \\
\text { Even when dis- } \\
\text { agreeing with } \\
\text { what others have } \\
\text { said, he/she } \\
\text { remains respectful } \\
\text { of different points } \\
\text { of view. }\end{array}$ & $\begin{array}{l}\text { Student waits } \\
\text { his/her turn } \\
\text { before speaking. } \\
\text { He/she gives } \\
\text { others a chance to } \\
\text { speak who may } \\
\text { not have already } \\
\text { spoken. Even } \\
\text { when passion- } \\
\text { ately disagreeing } \\
\text { with what others } \\
\text { have said, he/she } \\
\text { remains respectful } \\
\text { of other points of } \\
\text { view. }\end{array}$ \\
\hline
\end{tabular}

Fig. 3: Appendix-History and Citizenship discussion criteria

I decided that I would use one grid per student throughout the term. This way, students who did not find a particular topic especially engaging would not feel compelled to speak just because I was evaluating them. The grids would be used to assess general participation and quality of participation over a period of months. I also asked students to do written reflections about our discussions for homework. This way, even if they hadn't contributed to a discussion, I knew they had been carefully listening to, and assessing different arguments. This, I felt, was important for reaching a fair evaluation of student learning.

After reviewing the videotapes, teacher comments, student comments, and my own reflections I understood that in order to engage the students in fruitful discussions, they would first have to be confident in their knowledge of the topics being discussed and take an interest in the topics themselves. After having them reflect upon some of our first discussions, the comment I frequently heard was that they didn't know enough about a topic, or connect to the topic being discussed. Instead of using discussions as a way to discuss more abstract ideas, such as democracy and justice, I decided to base our discussions on concrete material we had learned, and which encouraged the students to take a stand or make important decisions about a certain issue.

\section{Year two.}

Initial research. After having laid the groundwork for my inquiry into class discussions, I spent much of the second year exploring different methods for organizing class discussion. Mercer and Littleton (2007) suggest structuring the classroom so 
students begin their discussion as a whole class, break into small groups, then return to the whole group with the results of their small group talk. Parker (2006), on the other hand, distinguishes between seminar discussions, which are more exploratory in nature, revealing the world, and deliberations, through which students have to assess arguments presented and draw their own conclusions. All discourse theorists involve educators in the process in very different ways, and it is up to the individual pedagogue to select the best method.

Generally, techniques a teacher chooses should reflect the discussion's end goal. For example, if the main goal of the discussion is to hear as many opinions on a given topic as possible, one might decide to use Cazden's technique of handing off (2001). This consists of asking the last person who spoke to choose the next person to speak based on a specific set of criteria. If the teacher would like a more genderbalanced discussion, she might ask every other person who hands off the discussion to choose a female. Or, if the same individuals tend to dominate the discussion, she might request that the discussion be handed off to people who haven't yet contributed. If it is required that every group member contribute one idea to the discussion, a talking stick can be passed around. In this way, teacher involvement in the discussion's basic structural components can create a more equitable learning environment.

Students need to be taught how to disagree, take criticism, and how to respond and listen to the spoken thoughts of others. There are a variety of ways to achieve this. Johnson and Johnson's model of Constructive Controversy (2009) is a brilliant way of encouraging students to engage with multiple perspectives on a topic - first by researching and arguing one point of view, then switching sides and preparing an argument for the opposite point of view. Finally, students must seek to take both perspectives into account by attempting to reach a consensus on a single view point.

Through my initial research, I also discovered that there are multiple ways to track students' reflections. I might choose, for example, to introduce students to the notion of triple-entry notebooks (Kooy \& Kanevsky, 1996) in which they can do prewriting, a post-discussion reflection, and exchange thoughts with me in the final column. This method allows teachers to keep one finger on the pulse of emergent student knowledge as well as possible impediments to discussion which an individual student might be experiencing. 
Continued experimentation. I am experimenting with many different methods, trying to find the ones which would work best for my students. I also put the criteria grid which I had developed with my students in the previous year to good use! Because I was fortunate enough to teach my Canadian history students for two years in a row, I felt that my students were on an exploratory journey with me. Moreover, they were excited each time I told them that we were going to have a class discussion, and they suggested the development of new discussion protocol-having a student moderator who would take note of whose turn it was to talk next and regulate the discussion. These acted as gatekeepers or facilitators, regulating the tempo, pace, and direction of our conversations. I began to feel that my students were not only taking ownership of the discussion process, but were also actively creating banks of knowledge and meaning from the topics I placed on the table.

Towards the end of the year, I felt I could separate myself from the discussions, and I began to note who spoke and what they said. I felt that I could begin to enjoy some of the fruits of my labour. The topics I selected for discussion were motivating and interesting for the students, relevant to our curriculum, and had been well researched by the students ahead of time. I was beginning to develop a systematic means of evaluating the students for their citizenship competency-with a tool they had helped develop! There were still many hurdles to overcome, however. I sometimes felt that our discussions lacked spontaneity; while the discussions were mostly respectful and well controlled by the students themselves, because they had to take turns while discussing, the discussions sometimes lacked the energizing, spirited dynamic which critical conversations often have. Furthermore, certain students still tend to participate more than others.

Once again, I am researching different ways of dealing with some of these issues. The more I discuss these problems with my colleagues, however, the more I realize that my action research project will never actually end! As a result of my research into class discussions and citizenship education, I have decided to write my Master's thesis on classroom discourse, a topic which naturally emerged from my inquiry. And, in spite of my present action research project, I am starting to see new areas of my practice I would like to improve upon and research further.

Sujata Saha and Kelly Von Eschen on inquiry learning in senior Mathematics classes. I, Sujata, am in my eighteenth year of teaching. This year I only teach grade 11 mathematics. I am also currently doing a Master's in Teaching Mathematics at Concordia University. My colleague, Kelly, has been a mathematics teacher for 13 years. She recently completed her Master's in Teaching Mathematics from 
Concordia University, and became interested in action research as a way to link and assess what she was learning at Concordia with what she was doing in her practice, wanting to be more of a participant in the ideas she was reading about. We are two teachers with a total of thirty-two years of classroom teaching experience between us.

What are our concerns? Besides teaching together, we have collaborated on many professional projects and have learned to trust and respect each other's approach to senior secondary mathematics teaching, in particular, and to education in general. We consider ourselves traditional math teachers, delivering a contentheavy curriculum with traditional notes, examples and assignments. We have always conscientiously read the government-issued curriculum documents, and have taught the full content of our courses. So, in 2009, when we knew that reform was imminent, we took our characteristic initiative and read the sections of the MELS documents that concerned us. We discovered that we were about to face a new and unusual pedagogical challenge. According to the program content documents, secondary $\mathrm{V}$ mathematics teachers were required to facilitate a 10-15 hour independent assignment (IA). This IA would take the form of investigations and would account for $10 \%$ of the allotted class time for the courses. This was not something we felt we could ignore.

Neither of us had done this type of assignment in our classes before. We were accustomed to very traditional teaching practices. The courses we teach are very content-driven and our approach has been effective for both of us. Our initial shock wore off, and our next step was to dive in and get as much information as possible so that we would be able to prepare ourselves for the coming school year. Our shock was to be more jaw dropping when we discovered that there were no resources to help us in this endeavor. We were being asked to implement a substantial curricular change, but we were given virtually no resources to do so, save for one page in the MELS documents.

The time allowance for this project was another of our concerns. We have always felt that in the senior math courses time is a precious commodity, and the last thing we wanted was to squander it in pursuit of a project that, initially, seemed to have very little value. That the reform documents contained inadequate guidance really did not surprise us, but it certainly vexed us. If this IA had to happen, who was going to provide us with the guidance we needed?

Why are we concerned? Indeed, the question of who was going to guide and support teachers in this regard was at the forefront of our concern. We were willing 
to do what MELS prescribed but we were wary of trusting the ministry to provide the necessary scaffolding for the IA. As the reform had made its way through Secondary grade levels, we had attended MELS implementation sessions for the new mathematics courses and had come away disappointed. At the sessions there was confusion, contradiction, resignation, frustration-and this from the presenters, not the participants! MELS had lost credibility as far as we were concerned and we immediately felt that the only way to prepare ourselves adequately for 2010 was to take the initiative to create some support of our own.

What experiences can we describe to show why we are concerned? As mentioned, adequate time to deliver the program has always been a principal concern. Since we had no experience with this type of unstructured project, we were scared. We were out of our element. We are used to very structured lessons and homework. What little the MELS documents did provide with regard to implementing the IA sounded completely counter to our usual style of teaching. Experience told us that many senior math teachers feel this way, and many teach the way that we do. We needed some clear, step-by-step procedural guidelines and there were none. What could we do? Were we able to create some support materials for ourselves and for others? Clearly we needed to take action.

We set about trying to clarify the purpose of the IA and through that exercise we would see a plan emerge. We discussed our problem with the Action Research Group. It was suggested that we consider having the students use the inquiry model for research, and we were provided with a copy of an existing inquiry lab developed by a group of teachers several years ago. As soon as we saw the design, we knew that this would be the building block for our own inquiry framework. We customized it to fit the particular needs of our math students. Because we were still very new to this type of instruction and learning, it was decided that we needed to pilot it with a group of students as soon as possible. In the winter of 2009 we began the process of framing our research question, testing our research tool and collecting data to assess the validity of our inquiry framework with a select group of Secondary 5 students. The action research process had begun.

\section{What kind of data will we gather to show the situation as it unfolds? Because}

we were developing and piloting simultaneously, we were able to collect data that provided us with feedback to make immediate improvements to the framework. Data came in the form of anecdotal student feedback following working sessions, written student surveys, our personal journals of the process, students' final products, and valuable feedback from colleagues. It was this data that allowed us to determine 
whether the goals of the IA, as directed by the MELS, were attainable using the framework. Now in the second phase of the action research process, we are using the framework with regular Secondary 5 classes throughout the school and continue to gather data for the purpose of further developing the framework. This data includes feedback from colleagues, our observations, and a larger pool of final products.

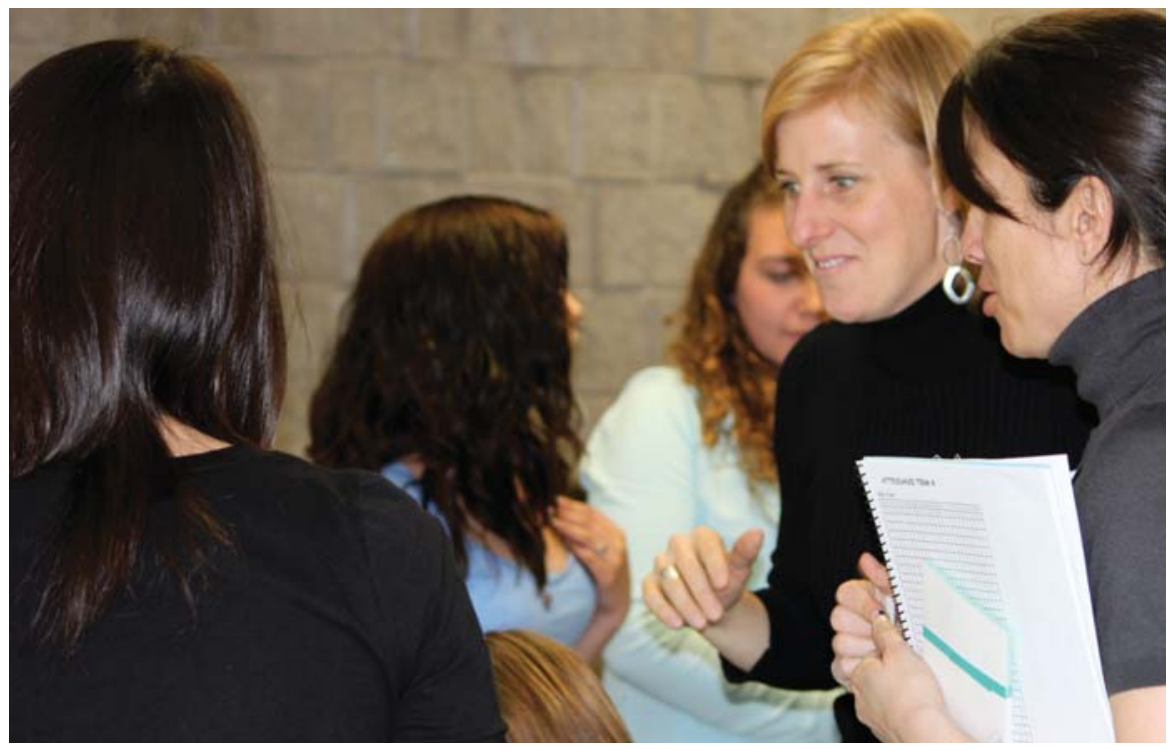

Fig. 4: Sujata (right) and Kelly evaluate student inquiry products at the Mathematics Fair

What evidence is there that we have made a difference? Not only did we do the project and bring our HRHS colleagues on board, but other teachers in various school boards have also used our tool to implement the IA component of the program. We have been in contact with teachers by email who have asked for more information or who have offered suggestions for improvement, based on their experiences with the tool that we created. We have given workshops that have been well received throughout the mathematics teaching community in Quebec. These contacts continue to re-energize our efforts to improve. Not only do we feel that our students have learned, but so have our colleagues. One teacher, in particular, came to one of our workshops quite skeptical that the project could be done or that it had any value, but by the end of our two-hour session he was not only convinced that it could, but also wanted to begin right away. The math teachers at our school felt that the tool kept the students on task and was instrumental in leading the students to a final product. They have taken the initiative to contribute to even more improvements for next year. The AR process is never over. 


\section{Conclusion}

In 1999, as reform initiatives were becoming the hot topic in school staffrooms, then Minister of Education, François Legault, called upon teachers to become the architects of the reform (MEQ, 1999). I believe that it can safely be said that the architects were left to their work without adequate understanding of blueprints or design tools. For some, action research has become a solution, but it is not the only tool available to professionals determined to understand the reform, tackle problems of practice and make change. In our developing CIPP, other activities include a Narrative Inquiry Group working at the intersection of story and self-study. As well, a group of teachers and support staff are working with students on social and physical problems in the school's environment using Action Research for Community Problem Solving (Poudrier, 1993). Still others are tackling issues faced by early career teachers, the need for differentiated instruction, problems of classroom management, and student motivation, through individual consultation. The common thread is that staff members are taking the initiative, and the risk, to seek problems and develop solutions. It is clear that this embedded professional development results in learning, and an understanding of that learning is becoming a new direction in work done in the CIPP in order that we better understand inquiry processes and practices, and resultant changing perspectives on teaching and learning.

\section{Notes}

1. This work has been funded in part by a Professional Development and Innovation Grant from MELS Québec.

\section{References}

Arhar, J., Holly, M., \& Kasten, W. (2001). Action research for teachers: Travelling the yellow brick road. Upper Saddle River, NJ: Merrill Prentice Hall.

Cazden, C.B. (2001). Classroom discourse: The language of teaching and learning. (2nd ed.). Portsmouth, $\mathrm{NH}$ : Heinemann.
Clandinin, J., \& Connelly, M. (1998). Personal experience methods. In N. Denzin \& Y. Lincoln (Eds.), Collecting and interpreting qualitative materials. Thousand Oaks, CA: Sage, 150-178. 
Clarke, A., \& Erickson, G. (Eds.). (2003). Teacher inquiry: Living the research in everyday practice. London: Routledge Falmer.

Connelly, M., \& Clandinin, J. (Eds.). (1999). Shaping a professional identity: Stories of educational practice. London, ON: Althouse.

Crick, R.D., \& Joldersma, C.W. (2007). Habermas, lifelong learning, and citizenship education. Studies in Philosophy and Education, 26(2), 77-95.

Denzin, N., \& Lincoln, Y. (1998). (Eds.), Collecting and interpreting qualitative materials. Thousand Oaks, CA: Sage.

Drummond, J., \& Themessl-Huber, M. (2007). The cyclical process of action research: The contribution of Gilles Deleuze. Action Research, 5(4), 430-448.

Gouvernement du Québec. (2004). Quebec education program (MEQ Publication No. 0300691). Quebec, CA: Author.

Heritage Regional High School. (2009). Educational project. Quebec, CA: Author.

Heydenrych, J. (2001). Improving educational practice: Action research as an appropriate methodology. progressio, 23(2), Retrieved September 23, 2009, from http://www.unisa.ac.za.

Johnson, D.W., \& Johnson, R.T. (2009). Energizing learning: The instructional power of conflict, Educational Researcher, 38(1), 37-51.

Kooy, M., \& Kanevsky, L. (1996). Searching for meaning in assigned readings: Using a triple-entry notebook, Teaching Education, $8,45-54$.

Lyons, N., \& Kubler LaBoskey, V. (Eds.). (2002), Narrative inquiry in practice: Advancing the knowledge of teaching. New York: Teachers College Press.
MEQ. (1999). Schoolscapes: The education reform newsletter, 1(3).

Mercer, N., \& Littleton, K. (2007). Dialogue and the development of children's thinking: A sociocultural approach. Oxford: Routledge.

Mills, G. (2003). Action research: A guide for the teacher researcher. Upper Saddle River, NJ: Merrill Prentice Hall.

Parker, W. (2006). Public discourses in schools: Purposes, problems, possibilities. Educational Researcher, 35(8), 11-18.

Poudrier, C. (1993). Action research for community problem solving. Trois-Rivières, QC: Author

Rath, A. (2002). Action research as border crossing: Stories from the classroom. In N. Lyons \& V. Kubler LaBoskey (Eds.), Narrative inquiry in practice: Advancing the knowledge of teaching. New York: Teachers College Press, 146-159.

Rust, F. (2002). Professional conversations: New teachers explore teaching through conversation, story, and narrative. In N. Lyons \& V. Kubler LaBoskey (Eds.). Narrative inquiry in practice: Advancing the knowledge of teaching. New York: Teachers College Press, 173-188.

Smith, W., Foster, W., \& Donahue, H. (1999). The contemporary scene in Québec: A handbook for policy makers, administrators and educators. Montreal, QC: OREP.

Stringer, E., Christensen, L., \& Baldwin, S. (2010). Integrating teaching, learning, and action research: Enhancing instruction in the K-12 classroom. Thousand Oaks, CA: Sage.

Van Manen, M. (1992). Researching lived experience. London, ON: Althouse.

Whitehead, J., \& McNiff, J. (2006). Action research living theory. Thousand Oaks, CA: Sage. 


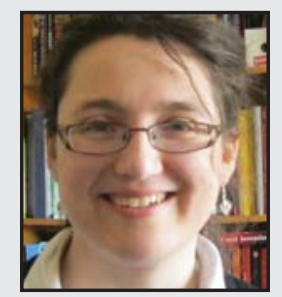

Danielle Couture graduated from McGill University in 2006 and is currently in her fifth year of teaching at Heritage Regional High School. Her passion for learning can be seen through her hobbies: dance, music, 3D rendering and filmmaking. When not in the classroom, you will most likely find her in the gymnasium coaching competitive cheerleading. She joined the action research group to better her practicum and learn more about the inquiry process. It is a wonderful fit as it coincides with her view of what a teacher really is: an avid learner who desires to share her passion.

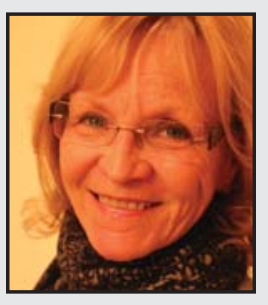

Judith McBride, $\mathrm{PhD}$ is a retired special education teacher. She currently serves as research coordinator at Heritage Regional High School of the Riverside School Board in Saint Hubert, Quebec. Her research interests include action research, instructional design, narrative inquiry, and teacher learning.

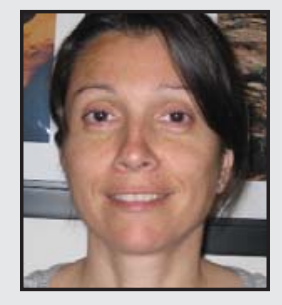

Sujata Saha taught senior high school mathematics for over 18 years on the South Shore of Montreal and is currently a vice principal at a high school in the same board. She has also been involved with the International Baccalaureate Middle Years Programme as a teacher, coordinator and workshop leader. Five years ago Sujata returned to pursue formal studies and recently completed a Master's in Teaching Mathematics. Education is her passion and she feels it is a journey where all involved must continuously look at best practices to keep up with the needs of the quickly evolving world. 


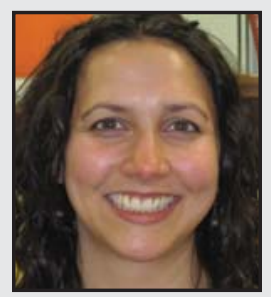

Denise Schellhase teaches Canadian History at Heritage Regional High School and is in her 13th year of the profession. She has a B.A. in Anthropology from the University of British Columbia and a teaching certificate from Simon Fraser University. Denise is currently completing her M.A. at McGill University and the topic of her thesis is classroom discourse and its role in identity development and critical thought. The inspiration for Denise's graduate work evolved from her action research project.

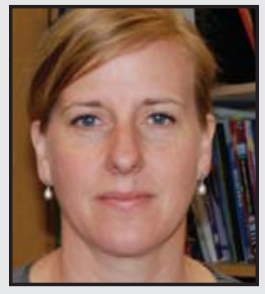

Kelly Von Eschen is a teacher of senior mathematics at Heritage Regional High School in St. Hubert. She has been teaching for 15 years and in 2009 she completed her Master's in Teaching Mathematics from Concordia University. She finds that the collaboration and collegiality inherent in action research is the balance she is looking for between academic research and the practice of her profession. 